\title{
Assessment of WRF/Chem Simulated Vertical Distributions of Particulate Matter from the 2009 Minto Flats South Wildfire in Interior Alaska by CALIPSO Total Backscatter and Depolarization Measurements
}

\author{
James Michael Madden ${ }^{1,2}$, Nicole Mölders ${ }^{1,2 *}$, Kenneth Sassen ${ }^{1,2}$ \\ ${ }^{1}$ Department of Atmospheric Sciences, College of Natural Science and Mathematics, University of Alaska \\ Fairbanks, Fairbanks, USA \\ ${ }^{2}$ Geophysical Institute, University of Alaska Fairbanks, Fairbanks, USA \\ Email: ${ }^{*}$ cmoelders@alaska.edu
}

Received 18 July 2015; accepted 25 August 2015; published 28 August 2015

Copyright (C) 2015 by authors and Scientific Research Publishing Inc.

This work is licensed under the Creative Commons Attribution International License (CC BY).

http://creativecommons.org/licenses/by/4.0/

(c) (i) Open Access

\section{Abstract}

This feasibility study examined whether total backscatter and depolarization measurements from Cloud Aerosol Lidar and Infrared Pathfinder Satellite Observations (CALIPSO) in combination with sparse surface meteorological data and other information permitted qualitative assessment of simulated vertical and horizontal distributions of aerosols from wildfires over Interior Alaska. Comparisons between co-located WRF/Chem cross-sections and CALIPSO curtains showed temporal and spatial differences in smoke-plume height above ground, vertical and horizontal extension. Simple estimates of contributions of errors and processes elucidated that the different spatial and temporal resolution of model grid-cells and the lidar scan could provide offsets of the magnitude found in the comparison. The overestimation of $10 \mathrm{~m}$ wind speeds by on average 1.33 $\mathbf{m} \cdot \mathrm{s}^{-1}$ contributed to the offset. Energy estimates suggested that the energy needed for permafrost thawing may contribute to discrepancies between simulated and CALIPSO indicated plume height. A sensitivity study with lower emission rates showed similar features. The study demonstrated that use of CALIPSO data in combination with data from other sources than air-quality networks could serve for identification of potential model shortcomings by assessment of magnitudes of error and process impacts.

${ }^{*}$ Corresponding author. 
Keywords

CALIPSO, MODIS, WRF/Chem, Wildfire-Smoke Distribution, Interior Alaska

\section{Introduction}

In the boreal forests of Alaska and northern Canada, particulate matter from wildfire smoke often endangers human health as well as prohibits small aircraft and ground traffic due to decreased visibility. Efforts in fire suppression, flight route planning, and public health advisories require information on plume propagation, extension, and height. The local weather offices issue forecasts of smoke propagation on a regular basis during the fire season (May/June to September). Due to the lack of surface air-quality monitoring networks and air-quality model simulations, these forecasts currently draw upon the experience of forecasters in interpreting numerical weather prediction and satellite data in terms of plume propagation, visibility reductions, and the potential of low air-quality in communities downwind of wildfires.

In North America, wildfire particulate matter is associated with increased hospitalizations and physician visits for respiratory issues and eye irritation [1]. The carbon monoxide and aldehydes released by wildfires can cause nausea, headaches, nasal irritation and/or enhance risks for cardiopulmonary complications [2]. In recent years, efforts to improve public air-quality awareness during wildfire episodes have been successful [3].

While the performances of various air-quality models in predicting anthropogenic and wildfire-caused aerosol distributions have been evaluated by means of data from surface and aircraft measurements [4], such evaluations are nonexistant for Interior Alaska. Here, the lack of data from aircraft field campaigns and the sparse availability of air-quality surface observations has limited the assessment of model performance.

Cloud Aerosol Lidar and Infrared Pathfinder Satellite Observations (CALIPSO) data can provide information on aerosol distributions with height along the flight path of the satellite [5] [6]. Moreover, the polarization lidar technique allows distinguishing between spherical and nonspherical atmospheric particles. It can determine unambiguously the thermodynamic phase of clouds and often identify the type of atmospheric aerosols because of its sensitivity to particle shape [7] [8]. Spherical aerosols (e.g. haze, aqueous smoke particles) produce little or no change in the polarization state of backscattered light [7] [8]. Intermediate and increasing depolarization ratios are found for aged (i.e. crystallized) sulfate haze and smoke aerosols [8].

In the past, space-borne lidar observations have proved themselves powerful tools for the evaluation of largescale models [9]-[12]. CALIPSO, for instance, carries the Cloud Aerosol Lidar with Orthogonal Polarization (CALIOP) that provides vertical profiles of attenuated backscatter [6]. Fractional cloudiness derived from CALIPSO data revealed shortcomings in simulated cloudiness by a climate model in a more pronounced fashion than evaluations based on passive observations [9]. CALIPSO lidar curtains and in situ aircraft measurements were analyzed to assess the model performance during the POLARCAT field campaign [11]. CALIOP data were used to evaluate Weather Research and Forcasting model [13] inline with chemistry (WRF/Chem) [14] simulated wildfire-plume heights over Asia [12]. Comparison of CALIPSO aerosol observations with aerosol simulations from the Goddard Chemistry Aerosol Radiation Transport (GOCART) model and aerosol optical depth (AOD) measurements from the MODerate resolution Imaging Spectroradiometer (MODIS) revealed that GOCART well captured the geographical patterns and seasonal variations of AOD especially near source regions [10]. It also identified regions where further development in simulating the magnitude of AOD was needed. This regional study considered, among other things, aerosols, and smoke from biomass burning in the midlatitudes and tropics.

In the subarctic, CALIPSO data provide curtains at relatively high spatial resolution (Figure 1). Given the successful use of CALIPSO data for large-scale model applications in mid and low latitudes and the high spatial resolution of CALIPSO data in the subarctic, we examined their feasibility for enhancing the predictability of aerosol distributions during wildfire plumes. Thus, we turned to level 1B CALIPSO products, surface meteorological, chemical and ground data to examine whether together they can provide useful information on WRF/ Chem's performance in predicting plumes from boreal wildfires and reasons for potential shortcomings.

\section{Experimental Design}

Our feasibility study focused on the Minto Flats South wildfire that was ignited by lightning on June 21, 2009. 


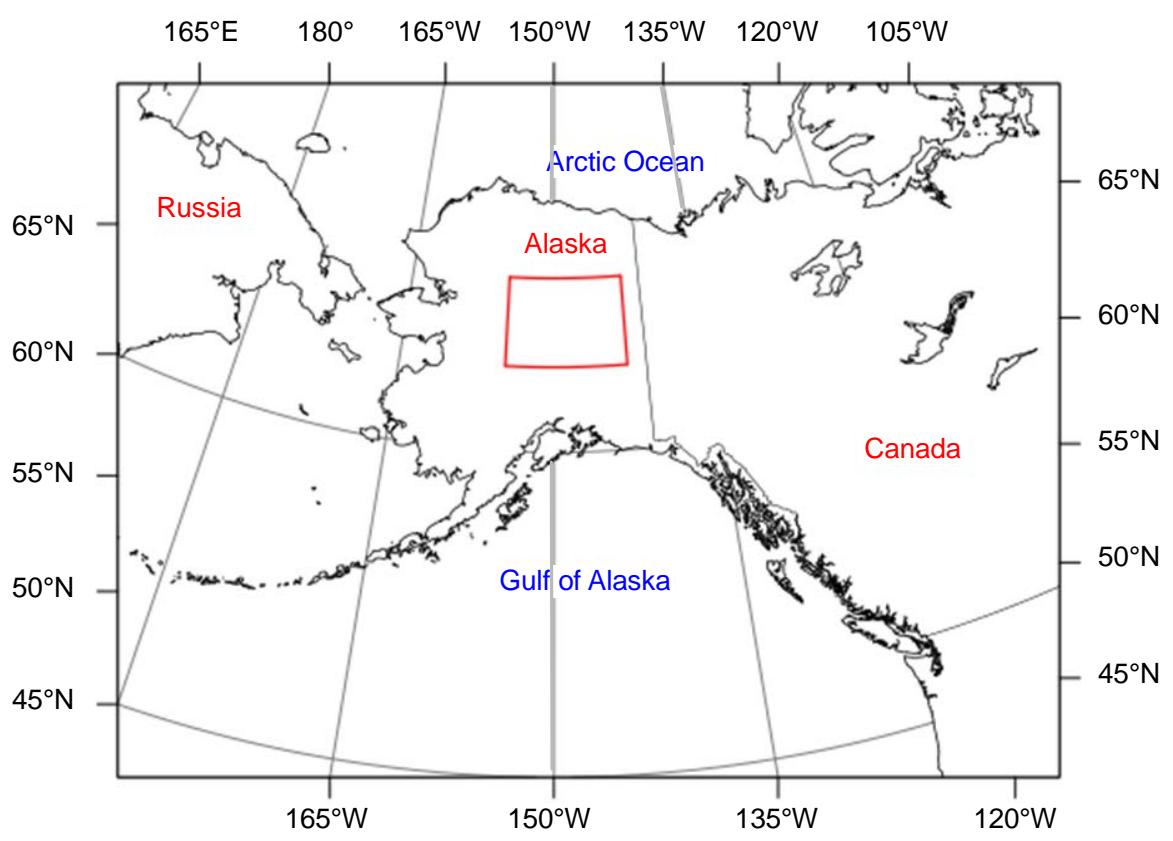

(a)

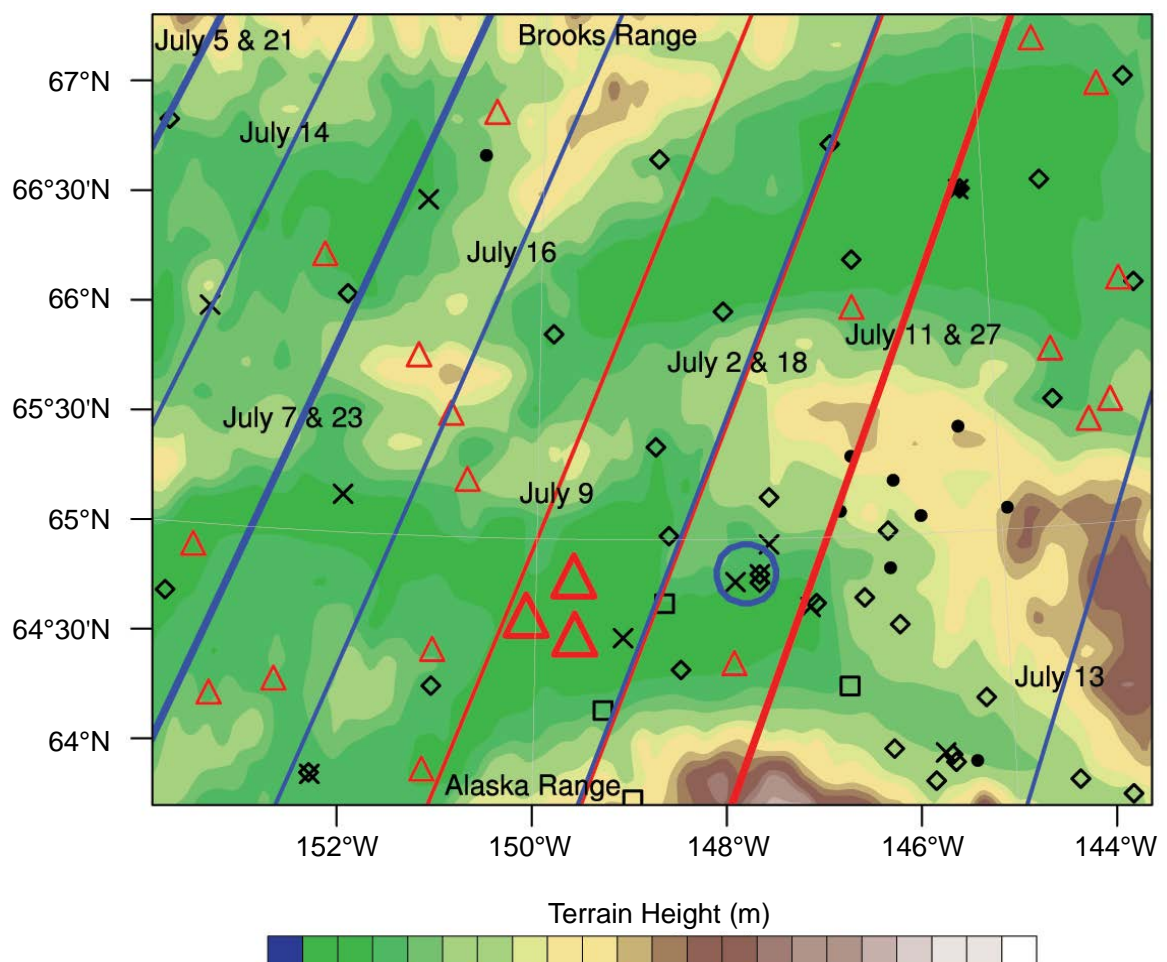

$0 \quad 200 \quad 400 \quad 600 \quad 800 \quad 1000 \quad 120014001600 \quad 18002000$

(b)

Figure 1. Model domain (a) location (red box) and (b) WRF/Chem terrain height (color shades), locations of observations stations, CALIPSO scan lines and the location of the Fairbanks Metropolitan region (blue circle). Red triangles, black crosses, black squares, and solid, black dots indicate the locations of remote automatic weather stations (RAWS), automated surface observing systems (ASOS), road weather information systems (RWIS) and snow telemetry stations (SNOTEL), respectively. The red lines indicate the cases discussed in the text. The blue lines represent scans excluded from explicit discussion. See text for details. 
This fire was the largest fire in the Railbelt Complex of fires named so due to the fires' vicinity to the railroad tracks. The fire burned over 300,000 acres (121,406 ha) by the end of July. This fire gained huge public interest due to an oil-drilling rig in the area. Our period of interest covered June 20 to July 30 of 2009, the day before the end of the Minto Flats South wildfire's main growth.

\subsection{Model Setup}

For our feasibility study, we used the WRF/Chem [14] in its Alaska-adapted [15] version with the Advanced Research WRF (ARW) [13] core. In WRF/Chem, meterorological, chemical, aerosol, and removal processes run in-sync with the same time step in the physical and transport schemes. The setup of WRF/Chem closely followed [16]'s Interior Alaska case study on the impacts of wildfires on weather. This setup included the interaction of clouds with aerosols and radiation [17], and the impact of absorbing gases and clouds on photolysis rates that are vital for air-quality simulations [18].

The Purdue-Lin scheme [19] and the Grell-3 scheme [20] considered cloud microphysics and cumulus convection at the resolvable- and subgrid-scale, respectively. Shortwave and long-wave radiation processes were calculated by the Goddard two-stream multi-band scheme [21] and the Rapid Radiative Transfer Model [22], respectively. Aerosol-radiation feedbacks were calculated following [17]. The Eta similarity scheme and the Mellow-Yamada-Janjić scheme [23] [24] considered surface and atmospheric boundary layer (ABL) processes. The improved Rapid Update Cycle land surface model [25] calculated heat and moisture fluxes, and considered soil moisture, frozen ground and soil temperature processes.

The chemical concentrations of reactive air constituents were calculated following [26]. The [27] scheme determined the frequencies of photolysis for 21 reactions as a function of, among other things, actinic flux, vertical profiles of cloud, aerosol, and other absorbing species. The Modal Aerosol Dynamics Model for Europe [28] and the Secondary Organic Aerosol Model [29] simulated the dynamics and reactions of organic and inorganic aerosols, and considered some aqueous-phase reactions. Dry deposition calculations followed [30] with the modifications for Alaska by [15].

\subsection{Emissions}

The Emission Database for Global Atmospheric Research version 4.1 [31] provided global annual anthropogenic emission data for several greenhouse and precursor gases on a $1^{\circ} \times 1^{\circ}$ grid. The data was downscaled onto the WRF/Chem domain using the method by [32]. Biogenic emissions of isoprene, monoterpenes, and volatile organic compounds from plant foliage, and nitrogen oxides from soil bacteria, were calculated inline with the emissions depending on land-cover, soil type and meteorological conditions [33] [34].

We used the Brazilian Biomass Burning Emissions Model (3BEM) [35]-[37] to estimate fire emissions and plume-rise characteristics. Daily data on wildfire location and spatial extension stemmed from the MODIS and the Fire Information for Resource Management System. This spatial and temporal wildfire information was merged with land-cover [38], and vegetation datasets [39] of $1 \mathrm{~km}$ resolution to determine factors of emission, carbon density characteristics, and combustion for the various boreal land-cover vegetation types [40] [41]. The masses of pyrogenic emissions within each fire pixel were calculated as a function of vegetation-type, the availability of above-ground biomass, and the area of burning land [16]. The 3BEM calculated plume-rise based on the aforementioned environmental datasets, remote sensing data and thermodynamical concepts of pyro-convection. The one-dimensional time-dependent cloud model by [36] served to calculate the convective transport. Herein, the calculation of plume rise and height considers the surface heat flux and positive buoyancy produced by the fire and release of latent heat, the reduction of buoyancy and plume dilution by mixing with ambient air, and the thermodynamic stability of the environment [16]. The plume-height locations were fed into the emission field of WRF/Chem [36] [42]. The emitted materials were dispersed and were transported in dependence of the simulated wind fields.

\subsection{Simulations}

The domain of interest covered Interior Alaska with $200 \times 160$ grid points (Figure 1) of $2 \mathrm{~km}$ increment and 28 vertical layers from the surface to $100 \mathrm{hPa}$. Meteorological initial and boundary conditions were downscaled from the $1^{\circ} \times 1^{\circ} 6 \mathrm{~h}$ resolution global final analyses [43] from the National Centers for Environmental Predic- 
tion.

Idealized vertical profiles of average Alaska chemical background concentrations served as initial and lateral boundary conditions. Sensitivity studies showed that in pristine areas, differences in the order of natural variation in the lateral boundary conditions still allow for acceptable signal-to-noise ratios for single anthropogenic emission sources [44]. The first three days of the simulation period were discarded for spin-up of the chemical fields.

Meteorological fields were re-initialized every five days. The chemical fields obtained at the end of the previous day served as initial values for the next day. Note that due to this procedure some inconsistencies between the chemical and meteorological fields may occur at the beginning of each re-initialization. However, [45] showed that these effects are marginal most of the time confirming the earlier findings by [15].

\subsection{Analysis}

WRF/Chem results were compared with hourly surface meteorological observations of $2 \mathrm{~m}$ temperature, $2 \mathrm{~m}$ relative humidity, precipitation, $10 \mathrm{~m}$ wind speed and direction, sea-level pressure, daily accumulated downward shortwave radiation, daily accumulated precipitation, and daily maximum and minimum $2 \mathrm{~m}$ temperatures. The observations stemmed from multiple sources due to observation station scarcity (Figure 1). Hourly measurements were conducted by 32 remote automatic weather stations (RAWS; Western Regional Climate Center), 11 automated surface observing systems (ASOS; National Climatic Data Center), four road weather information systems (RWIS; Alaska Department of Transportation and Public Facilities), and ten snow telemetry sites (SNOTEL; U.S. Dept. of Agriculture's Natural Resources Conservation Service). Some of the 57 observation sites only reported a subset of the aforementioned meteorological quantities. We evaluated WRF/Chem's meteorological performance based on all available data by determining the bias (simulated minus observed), root mean square error (RMSE), standard deviation of error (SDE), and correlation skill scores.

Due to the remote location, hardly any chemical monitoring existed [15]. Measurements of particulate matter of $2.5 \mu \mathrm{m}\left(\mathrm{PM}_{2.5}\right)$ and $10 \mu \mathrm{m}\left(\mathrm{PM}_{10}\right)$ in diameter were available from the Denali Interagency Monitoring of Protected Visual Environments (IMPROVE) site on a 1-in-3-days basis with some data missing. Furthermore, hourly and $24 \mathrm{~h}$ means of $\mathrm{PM}_{2.5}$ were available from the Fairbanks State Office Building site. Due to the limited amount of surface particulate-matter data, calculations of skill-scores are of low meaning. Therefore, comparison served only to assess whether simulated and observed data agree within a factor of two and had similar temporal evolution.

Within the framework of this study, we focused on the $0.532 \mu \mathrm{m}$ wavelength of CALIOP. In addition, backscatter data were used to express the sizes, shapes, and orientations of suspended aerosols through the linear depolarization ratio (LDR) following [7] [8] [46] [47]. The LDR is a ratio of backscattering powers (as a function of range) in both polarization planes (perpendicular to parallel) [46]. In theory, if particles are perfectly spherical, no backscattering in the perpendicular, or orthogonal plane, should occur. This means irregularly shaped particles cause perpendicular backscattering [7] [48].

Smoke particles are generally spherical in nature [49]. Thus, they produce near-zero perpendicular backscatter and very little depolarization [50] [51]. Slightly elevated depolarization values are associated with aged smoke, which may be due to particle coagulation or an inclusion of soil matter into the plume [49]. Previous studies found that depolarization values of $6 \%$ typically occur in the upper part of a smoke layer, and comparatively lower depolarization percentages occur below the active layer [50] [52]. Depolarizations of $3 \%$ and $5 \%$ indicate fresh smoke and smoke layers at higher altitudes, respectively [48].

Our analysis focused on overpasses with as few clouds as possible, as clouds affect the depolarization ratio and overshadow smoke signatures [48]. Moreover, our analysis used nighttime CALIPSO data to reduce possible interference from the Sun. During nighttime, namely, the $0.532 \mu \mathrm{m}$ calibration constant can be determined for each $55 \mathrm{~km}$ averaged profile (11 frames) by means of the $0.532 \mu \mathrm{m}$ parallel signals in $30-34 \mathrm{~km}$ height and the molecular and ozone number densities obtained from a scattering model [5]. However, during daytime, solar light degrades the backscatter signal-to-noise ratio below usuable levels. The noise associated with solar background light makes the application of the aforementioned calibration technique impossible. Therefore, the calibration constants of a daytime orbit's adjacent nighttime orbits are interpolated to determine the calibration constant for the daytime portion of the orbit [5].

In the comparisons between WRF/Chem simulated aerosol distributions and CALIPSO lidar curtains, we as- 
sumed that the particles observed by CALIPSO have diameters less than or equal to $10 \mu \mathrm{m}$. CALIPSO backscatter and depolarization data were compared along the same latitude and longitude to WRF/Chem simulated $\mathrm{PM}_{10}$. Cross-section comparisons over the satellite path evaluated how WRF/Chem simulated smoke plumes as a function of location, height and horizontal extension. Figure 1 features CALIPSO scan tracks and their respective dates.

\section{Results and Discussion}

Various studies concluded that accurate performance with respect to the meteorological variables is essential for acceptable chemical transport simulations [53] [54]. Therefore, we presented an evaluation first prior to the discussion of WRF/Chem's performance with respect to predicting particulate matter vertical and horizontal (along the flight path) distributions.

\subsection{Meteorology}

WRF/Chem well captured the temporal evolution of $2 \mathrm{~m}$ air temperature and its variation over the domain (Figure 2). Skill scores indicated a slight overestimation of hourly temperatures, an underestimation of the diurnal temperature range, and an underestimation of the spatial variability of observed temperatures (Table 1 , Table 2). Some of the overestimation can be attributed to underestimations in simulated cloud cover according to comparison of WRF/Chem's cloud related fields with the CALIPSO and MODIS data. WRF/Chem namely started with zero cloud and precipitation particles in every re-initialization period (Section 2.1). Furthermore, comparison of cloud-free MODIS visible images of summer 2009 and the WRF/Chem used fuel-type and land-cover data showed notable discrepancies similar to the discrepancies reported for land-cover data by [55]. [56] showed that some errors in $2 \mathrm{~m}$ temperatures were attributable to differences in land-cover/use and soil-type, and terrain height. The performance with respect to $2 \mathrm{~m}$ temperature was similar to that of past WRF studies in Alaska [15] [57] [58] and other polar regions [55] [59].

WRF/Chem acceptably captured the temporal evolution of relative humidity, but overestimated relative humidity (Figure 2; Table 1, Table 2). Skill scores were similar to those from previous WRF studies in Alaska [57]. The overestimation of precipitation was a logical consequence of the slightly too wet and too warm atmosphere. According to MODIS data and the time of precipitation, most precipitation was convective. The low correlation between simulated and observed precipitation is typical for convective precipitation.

We compared WRF/Chem simulated cloudiness with MODIS data. This comparison revealed that WRF/Chem underestimated cloudiness under convective situations. Discrepancies mainly occurred in the mountainous regions of the domain. Here, valleys that are of subgrid-scale often triggered convection over the mountain ranges. Discrepancies also occurred where notable differences in land-cover occurred in either the model or nature. Similar discrepancies were found for summer convection over Siberia by [55]. Furthermore, WRF/Chem failed to capture pyro-clouds. Recall that only the wildfire emission pre-processor considered pyro-convection to determine the wildfire emissions [36].

WRF/Chem adequately simulated the temporal evolution of observed $10 \mathrm{~m}$ wind speeds (Figure 2), but overestimated its magnitude by $1.33 \mathrm{~m} \cdot \mathrm{s}^{-1}$ (Table 1 ). The skill scores fell in the typical performance range seen in previous WRF studies of the subarctic (e.g. [55] [57]). Note that WRF/Chem is known to overestimate wind speeds under calm synoptic conditions (e.g. [60]). Some errors were attributable to the representation of terrain height by the grid-cell mean terrain height and the assumption of the dominant land-cover type being representative for the area covered by the grid-cell. Comparison of MODIS visible and near-infrared images with the landcover and terrain distributions showed that even at a $2 \mathrm{~km}$ increment, many of the complex terrain and very heterogeneous land-cover features are still of subgrid-scale. Both those assumptions meant a smoother surface in the model than in nature, leading to enhanced wind speeds in comparison to observations [56]. Various longterm evaluations by radio soundings of WRF/Chem simulated vertical profiles of wind speed suggested increasing performance above 1 to $2 \mathrm{~km}$ height (e.g. [15] [61]).

WRF/Chem acceptably captured the temporal evolution of $10 \mathrm{~m}$ wind direction (Figure 2; Table 1, Table 2) with similar accuracy to past studies (e.g. [15]). The simulated and observed scalar $10 \mathrm{~m}$ mean wind directions were $181^{\circ}$ and $163^{\circ}$, respectively.

WRF/Chem also adequately captured the temporal evolution of observed pressure with overall hourly mean bias, RMSE, SDE, and correlation of $-0.4 \mathrm{hPa}, 0.9 \mathrm{hPa}, 0.8 \mathrm{hPa}$, and 0.993 , respectively (Table 1 ). 


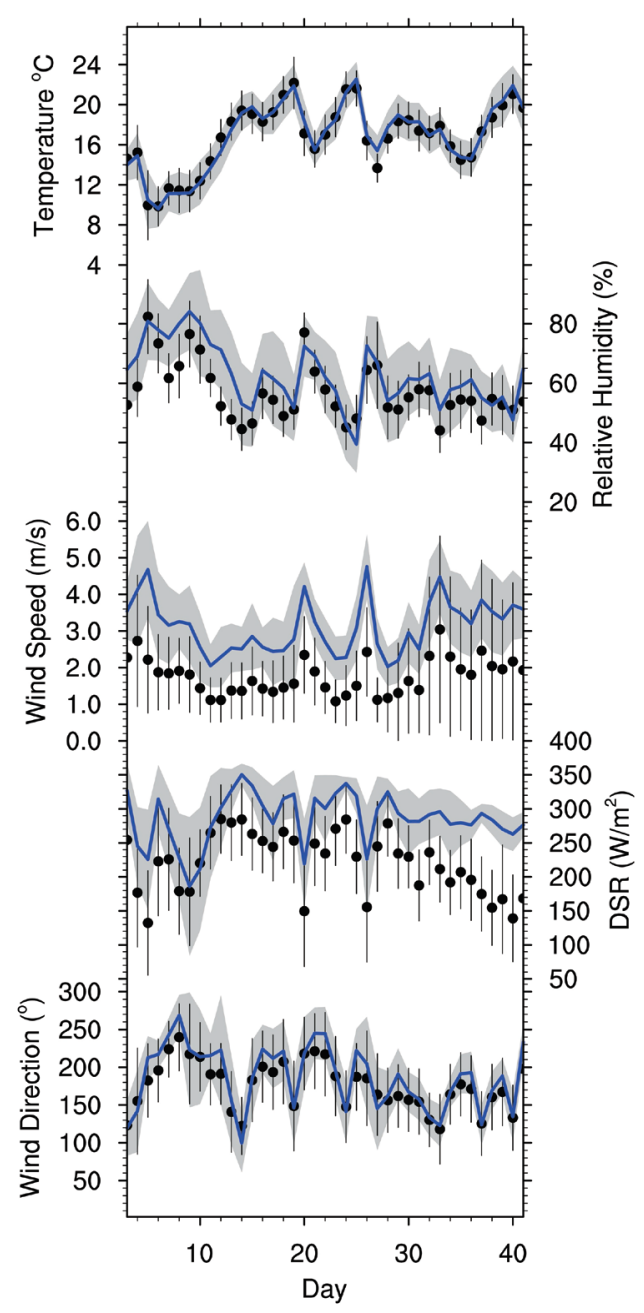

Figure 2. Temporal evolution of spatial daily mean $2 \mathrm{~m}$ temperature, $2 \mathrm{~m}$ relative humidity, $10 \mathrm{~m}$ wind speed, downward shortwave radiation (DSR), and $10 \mathrm{~m}$ wind direction. Black dots and bars represent the spatial daily means of the observations with spatial standard deviations (averaged over all sites with available data). The blue line and grey shade represent the spatial daily mean of the simulated quantity at the grid points of the observational sites and the daily mean spatial standard deviation of the quantity at these grid points.

Table 1. Summary of skill scores for hourly data. Data columns include the mean \pm the standard deviation, the root-mean square error (RMSE), the standard deviation of error (SDE), the bias (simulated minus observed), and the correlation (R) for period averages of available meteorological data during the period of interest.

\begin{tabular}{lcccccc}
\hline \multicolumn{1}{c}{ Quantity } & \multicolumn{3}{c}{ Hourly data } & & \\
& \multicolumn{1}{c}{ Simulated } & Observed & RMSE & SDE & Bias & $\mathrm{R}$ \\
\cline { 2 - 6 } $2 \mathrm{~m}$ temperature $\left({ }^{\circ} \mathrm{C}\right)$ & $16.7 \pm 5.3$ & $16.5 \pm 6.1$ & 3.2 & 3.2 & 0.1 & 0.847 \\
$2 \mathrm{~m}$ rel. humidity $(\%)$ & $9.2 \pm 3.7$ & $7.4 \pm 3.2$ & 4.1 & 3.7 & 1.8 & 0.455 \\
Precipitation $(\mathrm{mm})$ & $0.1 \pm 0.5$ & $0.1 \pm 0.4$ & 0.5 & 0.5 & $\sim 0$ & 0.215 \\
$10 \mathrm{~m}$ wind speed $\left(\mathrm{m} \cdot \mathrm{s}^{-1}\right)$ & $3.08 \pm 1.65$ & $1.76 \pm 1.79$ & 2.35 & 1.94 & 1.33 & 0.367 \\
$10 \mathrm{~m}$ wind direction $\left({ }^{\circ}\right)$ & $181 \pm 100$ & $163 \pm 102$ & 115 & 111 & 13 & 0.338 \\
Sea-surface pressure $(\mathrm{hPa})$ & $1013.04 \pm 7.90$ & $1013.41 \pm 8.06$ & 0.9 & 0.8 & -0.4 & 0.993 \\
Shortwave radiation $\left(\mathrm{W} \cdot \mathrm{m}^{-2}\right)$ & $289 \pm 269$ & $220 \pm 232$ & 173 & 158 & 71 & 0.810 \\
\hline
\end{tabular}


Table 2. Summary of skill scores for daily data. Data columns include the mean \pm the standard deviation, the root-mean square error (RMSE), the standard deviation of error (SDE), the bias, and the correlation (R) for period averages of available meteorological data during the period of interest.

\begin{tabular}{|c|c|c|c|c|c|c|}
\hline \multirow{2}{*}{ Quantity } & \multicolumn{6}{|c|}{ Daily data } \\
\hline & Simulated & Observed & RMSE & SDE & Bias & $\mathrm{R}$ \\
\hline $2 \mathrm{~m}$ temperature $\left({ }^{\circ} \mathrm{C}\right)$ & $16.6 \pm 3.9$ & $16.6 \pm 3.8$ & 1.6 & 1.6 & 0.1 & 0.913 \\
\hline $2 \mathrm{~m}$ rel. humidity (\%) & $61.9 \pm 15.6$ & $57.7 \pm 13.2$ & 13.0 & 12.3 & 4.2 & 0.646 \\
\hline Precipitation (mm) & $0.1 \pm 0.2$ & $0.1 \pm 0.2$ & 0.2 & 0.2 & 0.3 & 0.536 \\
\hline $10 \mathrm{~m}$ wind speed $\left(\mathrm{m} \cdot \mathrm{s}^{-1}\right)$ & $3.1 \pm 1.1$ & $1.8 \pm 1.4$ & 1.9 & 1.4 & 1.3 & 0.469 \\
\hline Sea-surface pressure (hPa) & $1013.1 \pm 7.8$ & $1013.4 \pm 7.8$ & 0.8 & 0.8 & -0.3 & 0.994 \\
\hline Shortwave radiation $\left(\mathrm{W} \cdot \mathrm{m}^{-2}\right)$ & $288 \pm 59$ & $220 \pm 74$ & 97 & 70 & 68 & 0.473 \\
\hline Maximum temperature $\left({ }^{\circ} \mathrm{C}\right)$ & $22.1 \pm 4.8$ & $23.1 \pm 5.5$ & 4.0 & 3.9 & -1.0 & 0.722 \\
\hline Minimum temperature $\left({ }^{\circ} \mathrm{C}\right)$ & $11.2 \pm 3.1$ & $9.6 \pm 4.2$ & 3.8 & 3.4 & 1.5 & 0.589 \\
\hline Accum. precipitation (mm) & $0.1 \pm 0.2$ & $0.1 \pm 0.2$ & 0.2 & 0.2 & $\sim 0$ & 0.530 \\
\hline
\end{tabular}

On average over the period and all sites, WRF/Chem overestimated daily-accumulated downward shortwave radiation by less than 21\% (Figure 2, Table 2). Overestimations of this magnitude were also found in other WRF studies (e.g. [58]). WRF/Chem missed the observed downward trend in incoming solar radiation near the end of the episode (Figure 2).

A combination of things played together. Only 36 sites reported downward shortwave radiation. Thus, small offsets of the plume due to biases in simulated wind speed and/or directions were decisive, whether or not a site was located under the wildfire plume and/or simulated clouds that blocked incoming radiation. Some errors in simulated downward shortwave radiation stemmed from the empirical parameterizations of the radiative effects of trace gases, aerosols, and emissions as well as errors in emissions and simulated concentrations.

In general, cloudiness was too low at the beginning of re-initialization periods if re-initialization coincided with cloudy conditions. In addition, as mentioned above, WRF/Chem tended to underestimate cloudiness. According to MODIS data, cloudiness was convective and locally triggered over mountain ridges by slope winds at the end of the simulation period. Under such conditions, the aforementioned discrepancies in land-cover and terrain height and subgrid-scale valleys and ridges led to discrepancies in sensible and latent heat fluxes, buoyancy, cloud formation and hence incoming solar radiation.

Some of the failures of capturing the low daily-accumulated downward shortwave radiation at the end of July were related to the response of permafrost to overlying fire. While WRF/Chem considered the emissions of trace gases and aerosols from biomass burning [16] [36], it did not consider thawing and sublimation of ice, nor the evaporation of water from permafrost underneath the fire that can be appreciable [62]. At the end of July, the fire namely had moved towards the Nenana River. This area is underlain by discontinuous permafrost, meaning permafrost exists mainly along creeks, rivers and on north facing slopes.

During FROSTFIRE, observations showed fire-induced changes in soil temperature, total volumetric soil water content (liquid plus solid) and its partitioning between the ice and liquid phase [63]. Sensitivity simulations suggested that two days with $600 \mathrm{~K}$ at the soil-fire interface increased soil temperatures on average about 3.1, $1.9,2.1$, and $1.6 \mathrm{~K}$ at $0.05,0.13,0.32$, and $0.80 \mathrm{~m}$ depth, respectively [62]. Concurrently, total volumetric water content was reduced to $86.4 \%, 83.1 \%$, and $80.4 \%$ of its original values in the upper 3 soil layers [62].

Most soil types when fully saturated have total volumetric water content between 39.5 (sand) and 49.2\% (silty clay) except for peat that has about 86.3\% [64]. An initially saturated sand layer of $0.05 \mathrm{~m}$ thickness and $2 \mathrm{~km} \times$ $2 \mathrm{~km}$, for instance, would contain $79000 \mathrm{~m}^{3}$ of water. Assuming the $13.6 \%$ loss from the above study [62] $10744 \mathrm{~m}^{3}$ of water would be released from this layer alone. Thus, the unaccounted for water-vapor emissions from thawing permafrost and subsequent formation of pyrocumulus also contributed the overestimation of accumulated downward shortwave radiation at the end of the episode. 


\subsection{Fairbanks Air-Quality and IMPROVE Data}

The Denali IMPROVE 1-in-3-days observations suggested slightly elevated $\mathrm{PM}_{10}$ background concentrations until July 3, 2009. Concentrations between 10.1 and $45.3 \mu \mathrm{g} \cdot \mathrm{m}^{-3}$ between July 6 and July 18 suggested the presence of wildfire smoke. The following days stayed at background concentrations. On July 30, the observed $27.8 \mu \mathrm{g} \cdot \mathrm{m}^{-3}$ of $\mathrm{PM}_{10}$ indicated again the presence of wildfire smoke (Figure 3). A statistical evaluation in terms of skill scores based on 15 data points (one missing value) is meaningless.

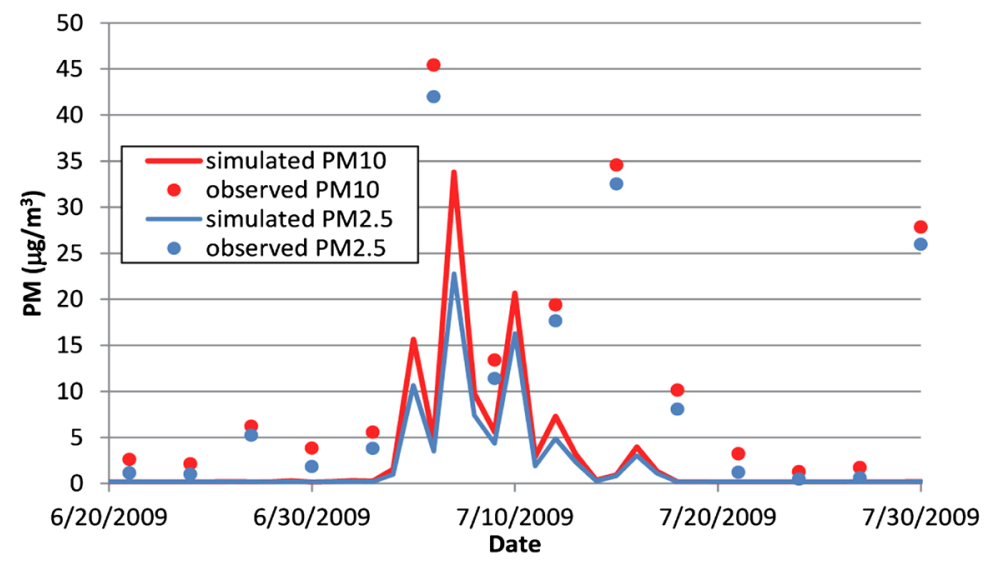

(a)
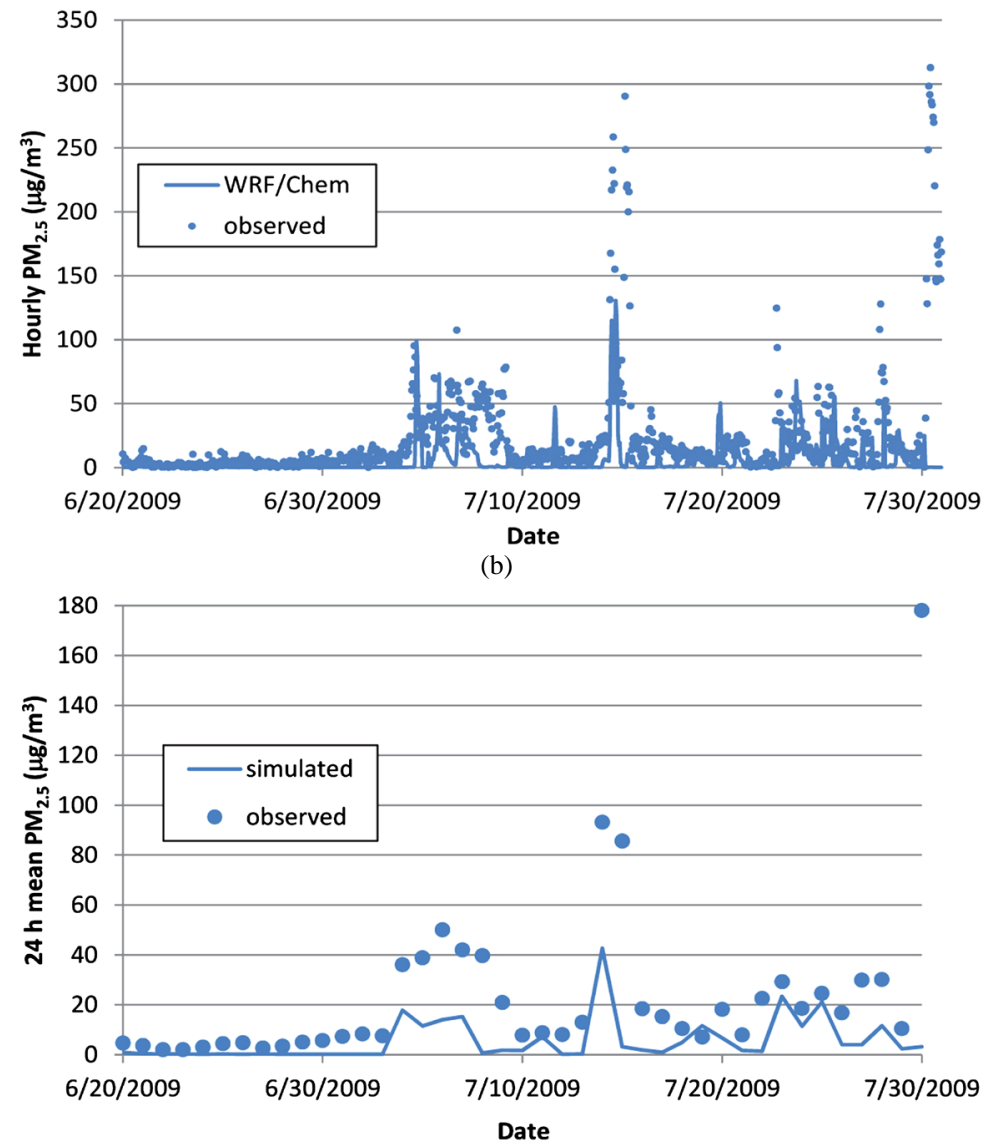

(c)

Figure 3. Simulated and observed concentrations of (a) $\mathrm{PM}_{10}$ and $\mathrm{PM}_{2.5}$ at the IMPROVE Denali site, (b) hourly and (c) 24 h mean $\mathrm{PM}_{2.5}$ at the State Office Building site in Fairbanks. Note that legends differ among panels. 
Comparison of the temporal evolution of these few observations suggested that WRF/Chem captured the situation broadly (Figure 3), but seemed to underestimate peak concentrations up to about a factor of two and slightly elevated concentrations by a factor of 5 to 10. The latter may be related to using mean background concentrations as lateral boundary conditions. The former was partly related to 1) offsets in wind direction, 2) local channeling effects inherent to the observations that are of subgrid scale in the model, 3) discrepancies in rainout due to discrepancies related to convective precipitation, and 4) keeping the wildfire emissions constant for 24 hours. Typically, wildfire emissions vary with time as they progress into areas with different fuel type and density and show a diurnal course. Furthermore, WRF/Chem simulated volume averages the grid-cell of the site, while the observations are point measurements. A sensitivity study that assumed wildfire emissions reduced by a factor of 100 provided a similar temporal evolution, but of course much lower concentrations [56].

Like for $\mathrm{PM}_{10}$ peaks WRF/Chem also underestimated the magnitudes of peak concentrations at the $\mathrm{PM}_{2.5}$ sites (Figure 3). Hourly $\mathrm{PM}_{2.5}$ data correlated weaker than $24 \mathrm{~h}$ averages as temporal offsets become more obvious on short periods than on daily periods. In case of the Fairbanks $\mathrm{PM}_{2.5}$ site, local sources may have contributed to discrepancies too, as the site is located near parking lots and a major highway. Nevertheless, these data suggested that WRF/Chem underestimated the $\mathrm{PM}_{2.5}$ concentrations notably. Some of this error can be attributed to the slightly too wet near-surface atmospheric conditions (Figure 2). Hyrophil $\mathrm{PM}_{2.5}$ swells and converts to PM $_{10}$ when enough water vapor is available [65].

Only the Denali IMPROVE site had $\mathrm{PM}_{2.5}$ and $\mathrm{PM}_{10}$ data. These data suggested that most of the particulate matter was $\mathrm{PM}_{2.5}$. This means it was in the range where it is health adverse.

\subsection{Plume Distribution}

Only the so-called nighttime CALIPSO scans were included for consistency of data quality (see Section 2.4). The CALIPSO scan tracks were indicated in Figure 1.

Smoke particles are generally spherical, and would be characterized as having signatures of light backscatter, near-zero perpendicular backscatter, and low LDR. On July 14 and 21, the area of interest was nearly overcast and did not allow for any assessment of the wildfire plume height due to the attenuation by the clouds. On July 5 and 13, the scans were outside of any smoke and/or significant wildfire activity. Due to partial cloudiness, many overpasses only allowed assessment of WRF/Chem's performance in predicting aerosols in small sections within the lidar curtain. However, these overpasses supported the basic findings and conclusions that we presented here by four examples. Note that the cloudy sections of these overpasses were considered in the above evaluation of cloudiness.

The four example cases were chosen as they had the fewest cloud contaminations according to the MODIS data (not shown). On those days, the general cloud distribution acceptably agreed with those found in the MODIS data with similar offsets for convective clouds than found for the smoke plumes in the ABL. In the following, we mainly focused on the smoke-plumes and showed examples for various cloudiness situations, i.e. thermodynamic conditions.

\subsubsection{Nearly Cloud-Free Cases}

The CALIPSO scan track and the July 18 qualitative comparison were featured in Figure 1 and Figure 4 , respectively. According to CALIPSO data, July 18 was largely cloud-free in the southern half of the cross-section. The CALIPSO data should predominantly feature wildfire related aerosols as the scan track was outside of the downwind influence of the Fairbanks metropolitan region. Other settlements within the area have less than 500 inhabitants.

Figure 4 indicates light total backscattering between 65.41 and $63.7 \mathrm{~N}$ latitude below an altitude of $3 \mathrm{~km}$. In addition, the perpendicular backscattering was near zero and the LDR was low. These criteria indicated the presence of smoke (see Section 2.4). Here, WRF/Chem and CALIPSO showed a plume-rise near the northern edge of the area of interest (the black box), however CALIPSO showed the plume rising lower toward the south. In addition, the WRF/Chem-simulated $\mathrm{PM}_{10}$ near the surface was skewed toward the north by several kilometers.

This spatial offset can be partly explained by the overestimation of wind speeds in the ABL and by the different nature of a WRF/Chem cross-section and a lidar curtain. Lidar-curtain soundings were made one after the other as time progresses, while model data shared the same time throughout the cross-section. The data in a 


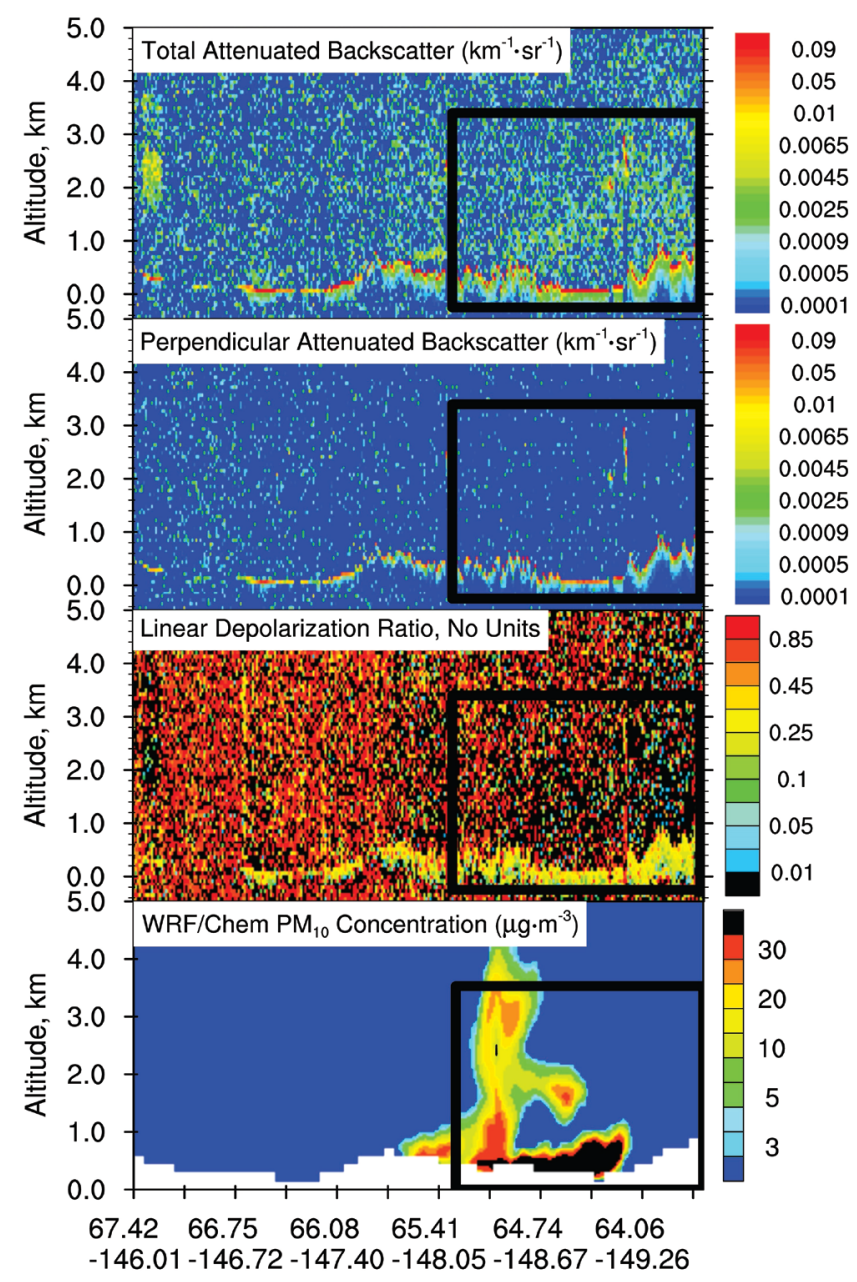

\begin{abstract}
Figure 4. The nighttime CALIPSO total attenuated backscatter, perpendicular attenuated backscatter, and LDR for 18 July 1203 to 1204 UTC, and the WRF/Chem model cross-section of $\mathrm{PM}_{10}$ concentration at 18 July 1200 UTC. Black boxes show areas with smoke activity. Smoke activity to the north is not highlighted as clouds block CALIPSO’s view.
\end{abstract}

WRF/Chem cross-section represented volumes of $2 \mathrm{~km}$ in horizontal and different vertical extension. The spatial and temporal resolution of the lidar was $100 \mathrm{~m}$ and $1 \mathrm{~s}$, respectively. Thus, the temporal difference between a model vertical profile and CALIPSO was about 20 minutes at maximum.

Since these facts applied to all comparisons, we presented the discussion of reasons in a generalized way based on the means of the entire episode rather than July 18. Assuming a mean $10 \mathrm{~m}$ wind speed of $1.76 \mathrm{~m} \cdot \mathrm{s}^{-1}$ as observed on average over the episode (Table 1), an air parcel would move about $2 \mathrm{~km}$ during that 20 minutes of time. However, WRF/Chem simulated a mean $10 \mathrm{~m}$ wind speed of $3.09 \mathrm{~m} \cdot \mathrm{s}^{-1}$, i.e. the air parcel would have traveled nearly $4 \mathrm{~km}$.

In addition, WRF/Chem predicted a plume-rise that was higher in altitude than suggested by the CALIPSO data (Figure 1, Figure 4). Potential reasons besides plume ejection height were the vertical resolution of the model, different fuel-types between the model and reality, and the neglect of thawing permafrost. In nature, some of the energy created by the fire was consumed for thawing of the permafrost and evaporating the resulting water in permafrost areas. Thus, in nature less energy was available to produce buoyancy. Water vapor is lighter than dry air and the (estimated) amount of water vapor released from permafrost should lead to buoyancy at higher levels upon condensation. Of course, vertical resolution, plume ejection height as well as the assumption of constant wildfire emission for the length of the day and at the same location contributed to discrepancies between simulated and observed plume aerosols. 
The CALIPSO scan track and the July 27 qualitative comparison were featured in Figure 1 and Figure 5, respectively. High clouds blocked CALIPSO readings of the near surface, south of the high terrain, while the scan otherwise was cloud-free. Figure 5 indicated light total backscattering between 66.75 and $65.41 \mathrm{~N}$ latitude below $2 \mathrm{~km}$. In addition, little perpendicular backscattering and low LDR existed in the same region, which indicated the presence of smoke. At higher levels, condensation may occur, which led to buoyancy by the release of latent heat. This means that in the immediate vicinity, the vertical profiles of buoyancy differed. A study investigating various combinations of heat, ash and water-vapor release during a volcanic eruption suggested that such differences can affect cloud formation and vertical temperature and moisture profiles up to $50 \mathrm{~km}$ downwind [66].

Like in the example of July 18 (Figure 4), WRF/Chem predicted notable amounts of $\mathrm{PM}_{10}$, but the $\mathrm{PM}_{10}$ plume reached higher in altitude than what the total backscatter and LDR indicated (Figure 5). The WRF/Chemsimulated $\mathrm{PM}_{10}$ showed again a northward skew by several kilometers. These discrepancies were similar to those found on other days and can be explained as above.

\subsubsection{Presence of High Thin Clouds}

The CALIPSO scans for July 9 and 11 were featured in Figure 6 and Figure 7. Like the cases presented above, WRF/Chem predicted $\mathrm{PM}_{10}$ in areas of light backscattering and near zero depolarization; however, the WRF/Chem simulated $\mathrm{PM}_{10}$ for July 9 was slightly shifted toward the north (Figure 6) as winds blew from a

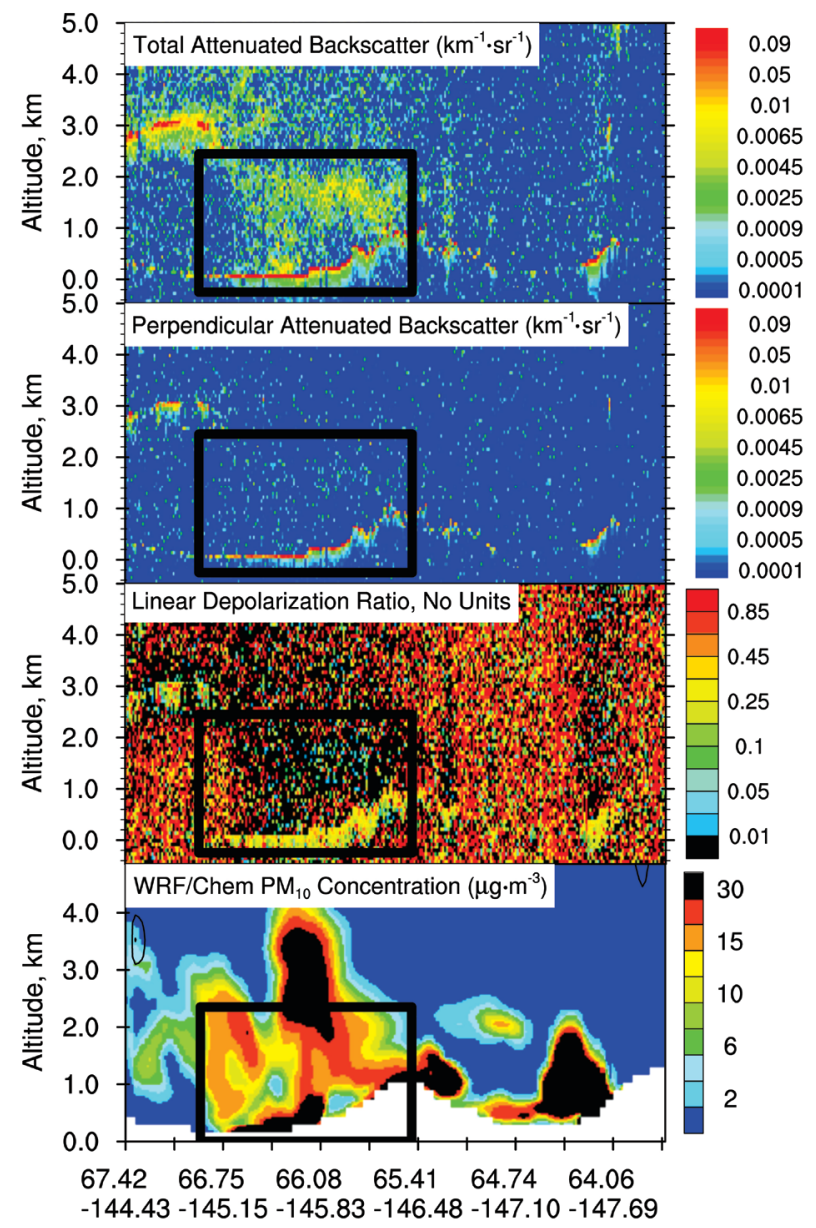

Figure 5. The nighttime CALIPSO total attenuated backscatter, perpendicular attenuated backscatter, and LDR for 27 July 1156 to 1157 UTC, and the WRF/Chem model cross-section of $\mathrm{PM}_{10}$ concentration at 27 July 1200 UTC. Black boxes show areas with smoke activity. Smoke activity to the south is not highlighted as clouds block CALIPSO's view. 


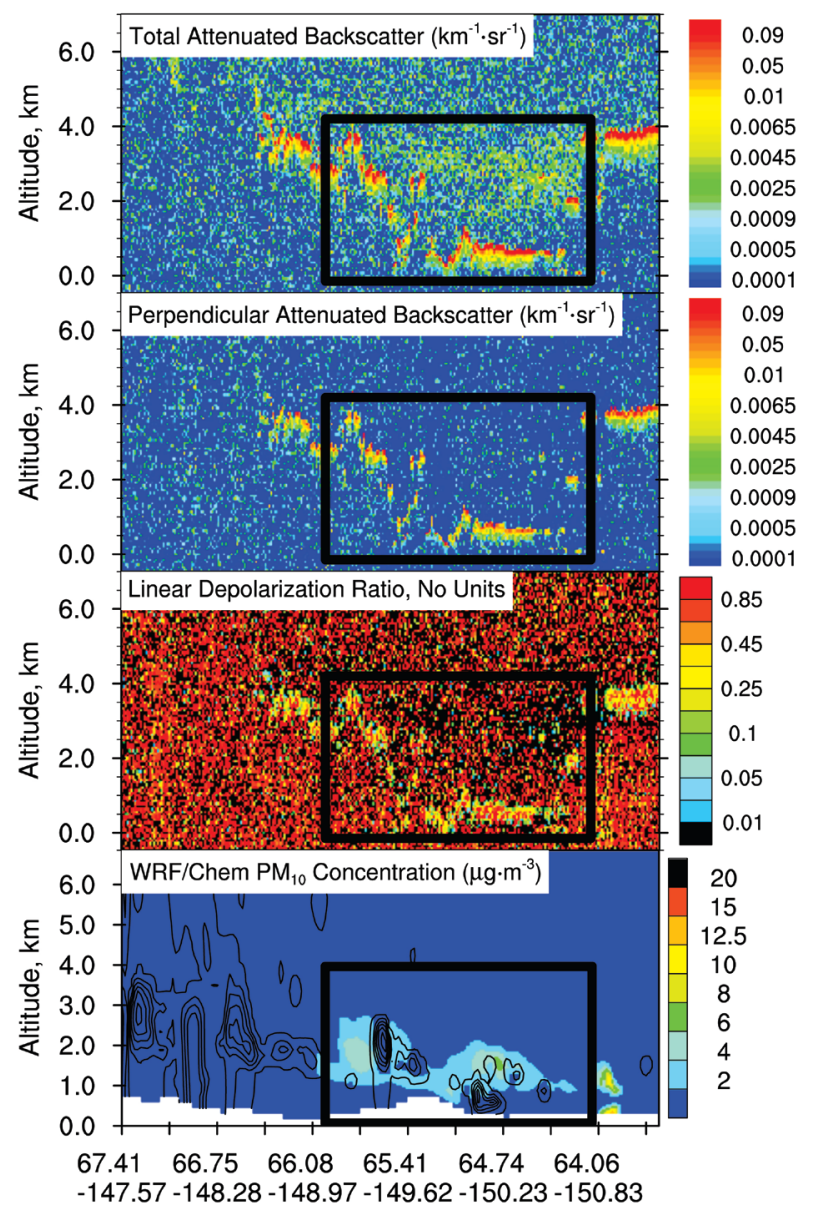

Figure 6. The nighttime CALIPSO total attenuated backscatter, perpendicular attenuated backscatter, and LDR for 9 July 1209 to 1210 UTC, and the WRF/ Chem model cross-section of $\mathrm{PM}_{10}$ concentration at 9 July 1200 UTC. Black boxes show areas with smoke activity. CALIPSO readings are blocked on the northern edge of the cross-section due to high cloud presence.

different direction on July 9 than on July 18 and 27 (Figure 4, Figure 6, Figure 8). WRF/Chem predicted a plume-rise that was slightly more north than what CALIPSO indicated. WRF/Chem clouds were lower in altitude by at least a kilometer, and clouds (higher than $6 \mathrm{~km}$ ) blocked CALIPSO's readings farther north.

The CALIPSO data of July 11 showed a small presence of smoke at the southern end of the cross-section (Figure 7). Like the other cases, WRF/Chem PM presence was more north by several kilometers, and the simulated PM was lower in both altitude and vertical extent. WRF/Chem also predicted cloud presence at the 4 to 6 $\mathrm{km}$ height level, within relatively the same ranges as what CALIPSO indicated; however, WRF/Chem cloud presence near the surface could not be evaluated as CALIPSO readings were blocked. This qualitative comparison provided evidence that WRF/Chem captured concentration gradients with height in an adequate manner, and supported the premise that discrepancies in plume location were caused by the overestimation of wind speed (Table 1, Table 2).

\subsection{Discussion}

Theoretically, model inaccuracies of temperature, humidity and/or downward shortwave radiation may cause errors in SOA formation. Analysis of the speciation, however, suggested only small shifts in the aerosol split of emitted and simulated aerosols.

Of course, WRF/Chem's well-known dampening of the diurnal temperature cycles [61] [67] needs to be addressed. It can affect convective available potential energy, reduce vertical mixing and the ABL height. However, 


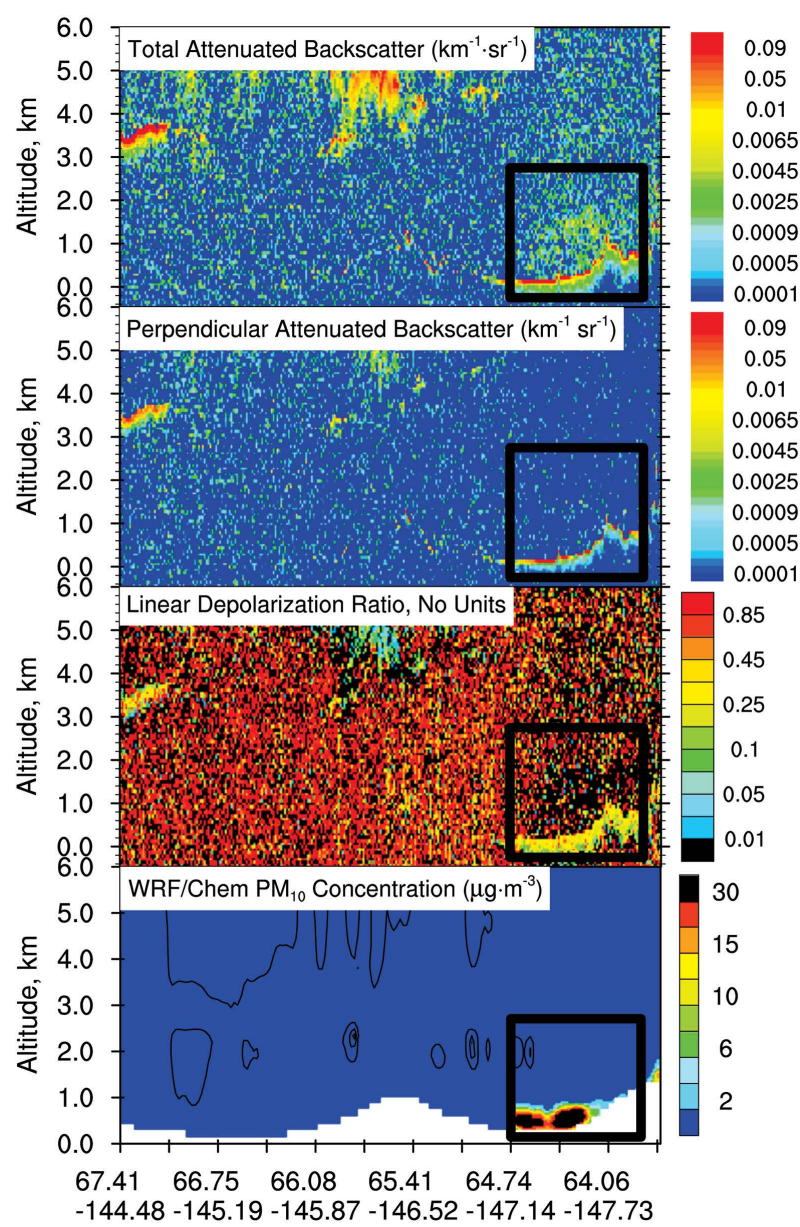

Figure 7. The nighttime CALIPSO total attenuated backscatter, perpendicular attenuated backscatter, and LDR for 11 July 1157 to 1158 UTC, and the WRF/Chem model cross-section of $\mathrm{PM}_{10}$ concentration at 11 July 1200 UTC. Black boxes show areas with smoke activity. Clouds block CALIPSO's view of the surface to the north.

these errors alone were too small to explain the discrepancies in plume vertical extension.

The release of heat from the fire, the release of water vapor from thawing permafrost, and the fire-related chemical reactions add appreciable buoyancy into the ABL. These releases can locally dominate the energy budget. The fact that both overestimation and underestimation in plume height occurred, hint at the interaction permafrost-fire as an important cause.

The analysis of permafrost maps in conjunction with MODIS and CALIPSO data suggested release of appreciable amounts of water vapor from the thawing permafrost under the wildfire. Such water-vapor release could explain the too high values of accumulated downward shortwave radiation predicted at the end of the episode. At least in the immediate vicinity of the source, those releases can affect vertical mixing and cloud processes notably or even significantly [66].

Water vapor, however, plays important roles in the atmospheric water, energy, and trace gas cycles. It affects temperature, and/or downward shortwave radiation as well as gasphase, aqueous phase and aerosol chemistry processes [65]. Since some of the gases released during the burn are involved in photochemistry as well as in aerosol formation, errors in simulated downward radiation may affect the atmospheric reaction paths and hence atmospheric composition. For all these reasons, the substantial release of water vapor from wildfires burning in permafrost regions should be included in future studies.

While CALIPSO permitted an excellent, qualitative evaluation of smoke presence, it has its limits. Some cases of excellent smoke activity had to be excluded from the analysis, simply because clouds blocked CALIPSO's 




July 9th, $1 \mathrm{~km}$ Daily Averaged Wind Speeds and Direction, \& $\mathrm{PM}_{10}$ Concentration $\left(\mu \mathrm{g} / \mathrm{m}^{3}\right)$

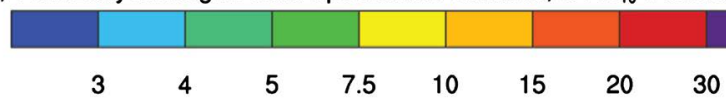

(a)

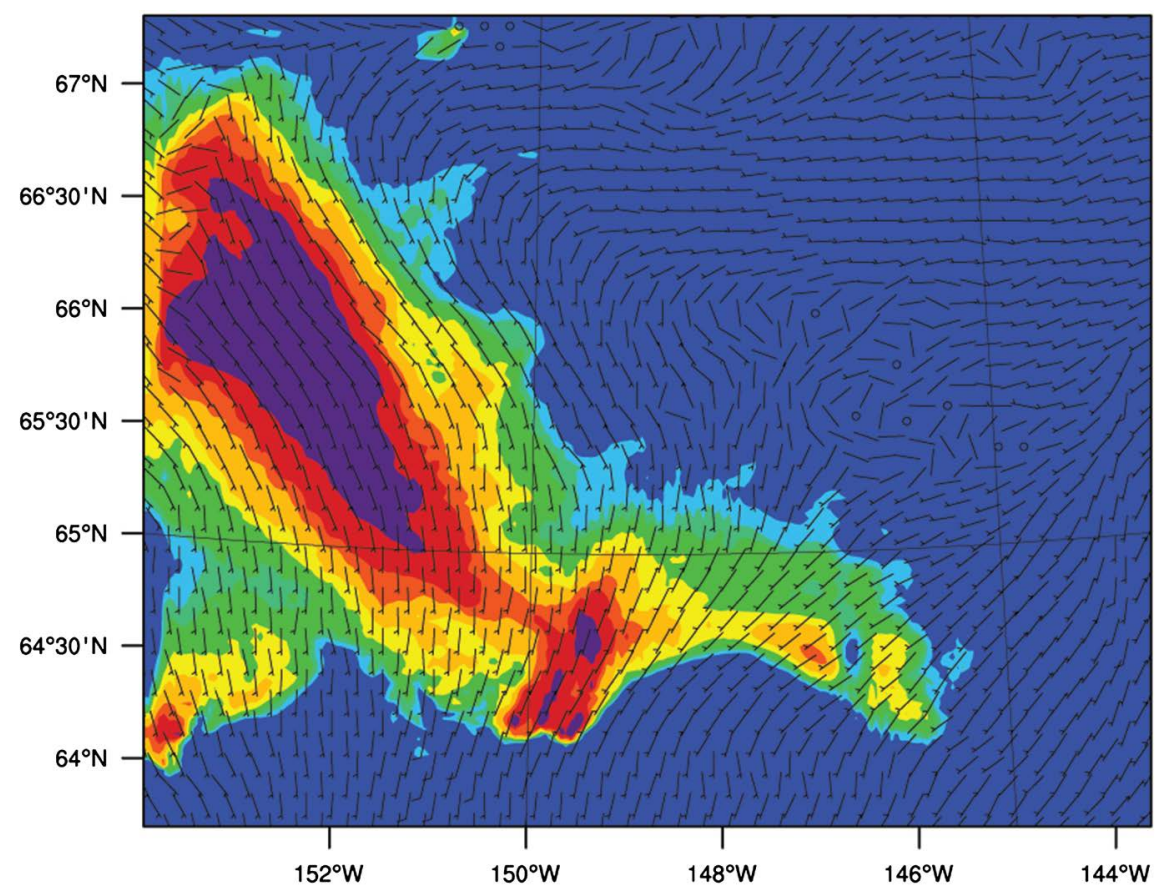

July 18 th, $1 \mathrm{~km}$ Daily Averaged Wind Speeds and Direction, \& $\mathrm{PM}_{10}$ Concentration $\left(\mu \mathrm{g} / \mathrm{m}^{3}\right)$

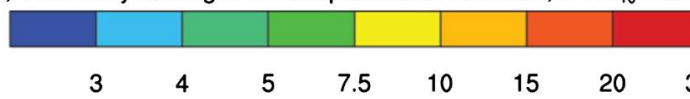

(b) 


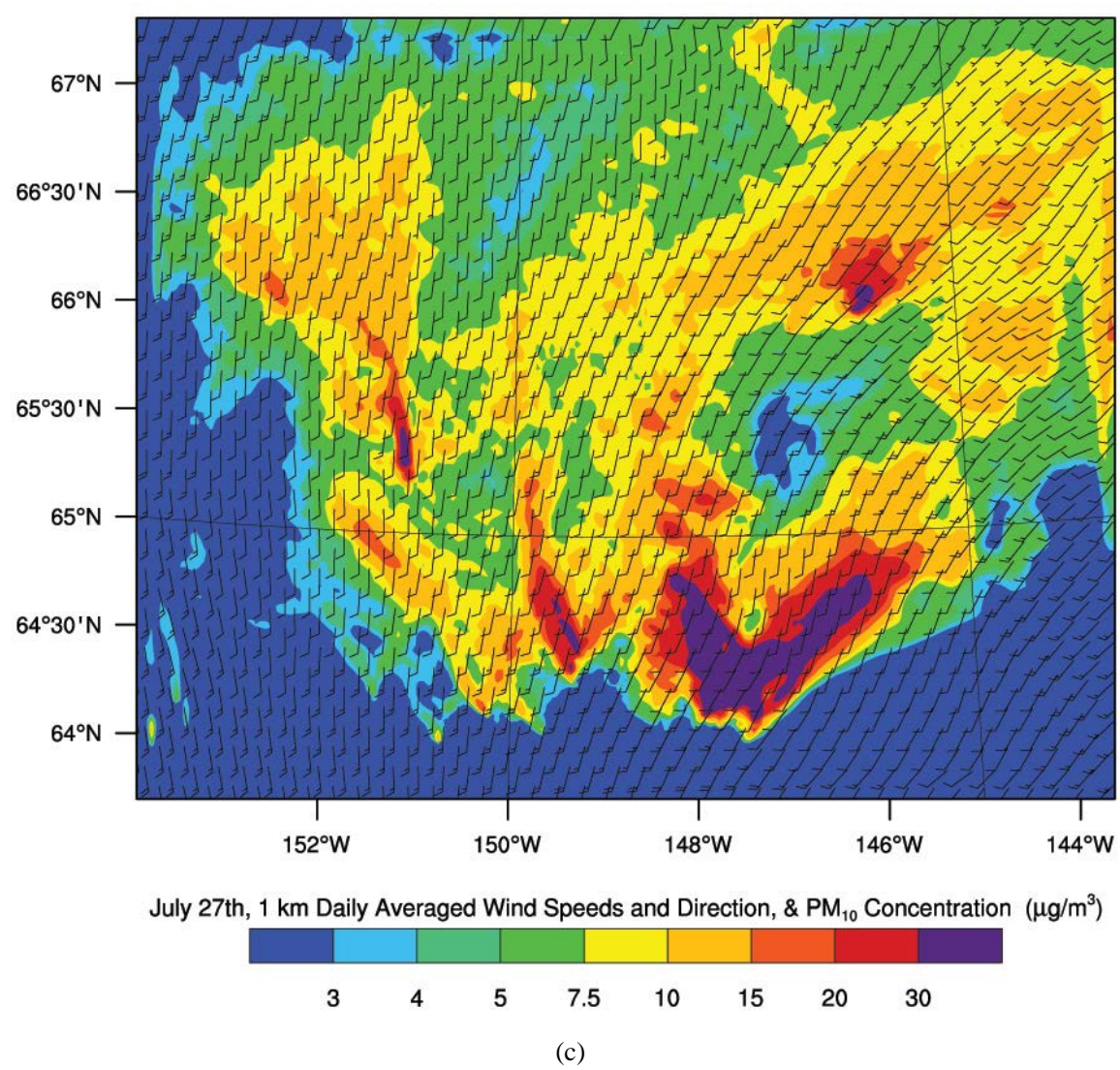

Figure 8. Mean wind directions and daily mean $\mathrm{PM}_{10}$ concentrations at about $1 \mathrm{~km}$ above ground level as obtained for (a) July 9, (b) July 18 and (c) July 27.

view, or because the CALIPSO scan path was too far away from any smoke activity. However, they were valuable in the evaluation of simulated cloudiness. Even when the CALIPSO scan path does come close to smoke activity on the ground, it may not pass over the most intense regions. On the available cloud free days, WRF/ Chem's smoke concentrations in the CALIPSO flight path were relatively low as compared to other areas of the plume or other times.

Additional research into quantitative CALIPSO analyses of smoke at the surface should be undertaken for the Arctic as it had been done for mid and low latitudes (e.g. [10] [12]). In these regions, studies that involved the use of aerosol optical depth and extinction showed promise [10] [12] [68]. However, this research must also feature the challenging task of sampling particulate matter concentrations at the surface to obtain a dataset that permits linking CALIPSO data to concentrations. Such data could be sampled, for instance, by unmanned aircraft in unaccessable areas, and/or by multiple ground-based air-quality measurements outside of city limits. Further analyses in this regard would permit improvement of the current state of the air-quality modeling in high latitudes. Such improvement is required for reasonable management decisions and air-quality advisories as the population grows in subarctic regions.

\section{Conclusions}

In high latitudes, hardly any surface observations of trace species and particulate matter exist. The few existing sites are biased toward regions of easy accessibility. Thus, air-quality model evaluations have been limited to short field campaigns. Therefore, we examined whether level 1B products from CALIPSO data in conjunction with other available data may provide means for evaluation and insights of model shortcomings that were needed for further development. The Minto Flats South wildfire near Fairbanks, Alaska served as a testbed to assess the performance of WRF/Chem in simulating the vertical and horizontal extent of wildfire-smoke plumes qualitatively over Interior Alaska. 
The qualitative comparison applied CALIPSO lidar curtains and WRF/Chem cross-sections of particulate matter concentrations along the same latitude and longitude. It indicated that 1) WRF/Chem predicted notable amounts of particulate matter in areas where backscatter and LDR plots indicated smoke presence, and 2) the predicted smoke-plume position and extent were acceptable. The different spatial and temporal resolutions of the WRF/Chem cross-sections and the lidar curtains contributed to offsets of several kilometers in the horizontal positioning of the plume. Furthermore, the overestimation of wind speeds led to too fast dispersion of smoke plumes. According to the few available observations, there is an offset of a factor of 2 or more in the PM concentrations. Systematic errors related to injection height, terrain height, model grid increments, and the discretization and treatment of soil- and land-cover type affected the magnitude of wildfire emissions. The constant emission rates over 24 hours led to further discrepancies in plume extension. A sensitivity study with a factor of 100 reduced wildfire emissions showed similar temporal evolution, but of course with much lower concentrations [56].

Estimates suggested that the errors in simulated $2 \mathrm{~m}$ temperatures were too small to explain differences in the vertical extent of the WRF/Chem simulated and CALIPSO observed smoke plumes. Thus, one has to conclude that WRF/Chem's lack of parameterizations to describe pyrocumulus clouds from wildfires and the daily constant emission rates are major contributors for errors in vertical extent.

While uncertainties in fuel-type and emission-ejection heights are potential reasons for the discrepancies in vertical plume extension, the combined data from permafrost maps, radiation measurements, MODIS and CALIPSO suggest the lack of water-vapor emissions due to thawing of underlain permafrost as a major issue. Thus, one has to conclude that developing a parameterization for the permafrost-fire interaction has high potential for improved results. Such parameterization, among other things, must consider the release of heat from the fire, the release of water vapor from thawing permafrost, and the fire-related chemical reactions in the soil, the flames, and the surface energy budget. In light of these shortcomings, WRF/Chem performed relatively well in predicting the spatial extent of smoke plumes over Interior Alaska.

\section{Acknowledgements}

We thank Anupma Prakash, Georg A. Grell, Michael A. Pirhalla and the anonymous reviewers for fruitful discussion, Jack Stickel from the Alaska Department of Transportation for access to his data, the Geographic Information Network of Alaska (GINA) and Cory Wolff for assistance with satellite images, and the National Weather Service Office of Fairbanks, Alaska for access to their smoke reports. The National Aeronautics and Space Administration provided funding (grant number: NASA-NNX11AQ27A). The Research Support Center with the Geophysical Institute at the University of Alaska Fairbanks provided access to HPC and data storage.

\section{References}

[1] Moore, D., Copes, R., Fisk, R., Joy, R., Chan, K. and Brauer, M. (2006) Population Health Effects of Air Quality Changes Due to Forest Fires in British Columbia in 2003: Estimates from Physician-Visit Billing Data. Canadian Journal of Public Health, 97, 105-108.

[2] Dominici, F., Peng, R.D., Bell, M.L., Pham, L., McDermott, A., Zeger, S.L. and Samet, J.M. (2006) Fine Particulate Air Pollution and Hospital Admission for Cardiovascular and Respiratory Diseases. Journal of the American Medical Association, 295, 1127-1134. http://dx.doi.org/10.1001/jama.295.10.1127

[3] Mott, J.A., Meyer, P., Mannino, D., Redd, S.C., Smith, E.M., Gotway-Crawford, C. and Chase, E. (2002) Wildland Forest Fire Smoke: Health Effects and Intervention Evaluation, Hoopa, California, 1999. Western Journal of Medicine, 176, 157-162. http://dx.doi.org/10.1136/ewjm.176.3.157

[4] Simpson, C.C., Pearce, H.G., Sturman, A.P. and Zawar-Reza, P. (2013) Verification of WRF Modelled Fire Weather in the 2009-10 New Zealand Fire Season. International Journal of Wildland Fire, 23, 34-45.

[5] Atmospheric Science Data Center (2006) CALIPSO Quality Statements Lidar Level 1B Profile Products. Version Release 3.00 .

https://eosweb.larc.nasa.gov/sites/default/files/project/calipso/quality_summaries/CALIOP_L1ProfileProducts_3.00.pdf

[6] Winker, D.M., Hunt, W.H. and McGill, M.J. (2007) Initial Performance Assessment of CALIOP. Geophysical Research Letters, 34. http://dx.doi.org/10.1029/2007gl030135

[7] Mishchenko, M.I. and Sassen, K. (1998) Depolarization of Lidar Returns by Small Ice Crystals: An Application to Contrails. Geophysical Research Letters, 25, 309-312. http://dx.doi.org/10.1029/97GL03764

[8] Sassen, K. (2000) Lidar Backscatter Depolarization Technique for Cloud and Aerosol Research. In: Mishchenko, M.I., 
Hovenier, J.W. and Travis, L.D., Eds., Light Scattering by Nonspherical Particles, Academic Press, San Diego, 393416. http://dx.doi.org/10.1016/B978-012498660-2/50041-0

[9] Chepfer, H., Bony, S., Winker, D., Chiriaco, M., Dufresne, J.-L. and Sèze, G. (2008) Use of CALIPSO Lidar Observations to Evaluate the Cloudiness Simulated by a Climate Model. Geophysical Research Letters, 35, Article ID: L15704. http://dx.doi.org/10.1029/2008GL034207

[10] Yu, H.B., Chin, M., Winker, D.M., Omar, A.H., Liu, Z.Y., Kittaka, C. and Diehl, T. (2010) Global View of Aerosol Vertical Distributions from CALIPSO Lidar Measurements and Gocart Simulations: Regional and Seasonal Variations. Journal of Geophysical Research, 115, Article ID: D00H30. http://dx.doi.org/10.1029/2009jd013364

[11] Sodemann, H., Pommier, M., Arnold, S.R., Monks, S.A., Stebel, K., Burkhart, J.F., et al. (2011) Episodes of CrossPolar Transport in the Arctic Troposphere during July 2008 as Seen from Models, Satellite, and Aircraft Observations. Atmospheric Chemistry and Physics, 11, 3631-3651. http://dx.doi.org/10.5194/acp-11-3631-2011

[12] Wang, J., Ge, C., Yang, Z.F., Hyer, E.J., Reid, J.S., Chew, B.-N., et al. (2013) Mesoscale Modeling of Smoke Transport over the Southeast Asian Maritime Continent: Interplay of Sea Breeze, Trade Wind, Typhoon, and Topography. Atmospheric Research, 122, 486-503. http://dx.doi.org/10.1016/j.atmosres.2012.05.009

[13] Skamarock, W.C., Klemp, J.B., Dudhia, J., Gill, D.O., Barker, D.M., Duda, M.G., et al. (2008) A Description of the Advanced Research WRF Version 3. NCAR/TN, 125 p.

[14] Peckham, S.E., Fast, J., Schmitz, R., Salzmann, M. and Freitas, S. (2011) WRF/Chem Version 3.3 User's Guide, 96 p.

[15] Mölders, N., Tran, H.N.Q., Quinn, P., Sassen, K., Shaw, G.E. and Kramm, G. (2011) Assessment of WRF/Chem to Capture Sub-Arctic Boundary Layer Characteristics during Low Solar Irradiation Using Radiosonde, Sodar, and Station Data. Atmospheric Pollution Research, 2, 283-299.

[16] Grell, G.A., Freitas, S.R., Stuefer, M. and Fast, J.D. (2011) Inclusion of Biomass Burning in WRF-Chem: Impact on Wildfires on Weather Forecasts. Atmospheric Chemistry and Physics, 11, 5289-5303. http://dx.doi.org/10.5194/acp-11-5289-2011

[17] Barnard, J., Fast, J., Paredes-Miranda, G., Arnott, W. and Laskin, A. (2010) Technical Note: Evaluation of the WRFChem “Aerosol Chemical to Aerosol Optical Properties” Module Using Data from the MILAGRO Campaign. Atmospheric Chemistry and Physics, 10, 7325-7340. http://dx.doi.org/10.5194/acp-10-7325-2010

[18] Grell, G.A., Peckham, S.E., Schmitz, R., McKeen, S.A., Frost, G., Skamarock, W.C. and Eder, B. (2005) Fully Coupled "Online" Chemistry within the WRF Model. Atmospheric Environment, 39, 6957-6975. http://dx.doi.org/10.1016/j.atmosenv.2005.04.027

[19] Lin, Y.-L., Rarley, R.D. and Orville, H.D. (1983) Bulk Parameterization of the Snow Field in a Cloud Model. Journal of Applied Meteorology, 22, 1065-1092. http://dx.doi.org/10.1175/1520-0450(1983)022<1065:BPOTSF>2.0.CO;2

[20] Grell, G.A. and Dévényi, D.A. (2002) Generalized Approach to Parameterizing Convection Combining Ensemble and Data Assimilation Techniques. Geophysical Research Letters, 29, 38-1-38-4.

[21] Chou, M.-D. and Suarez, M.J. (1994) An Efficient Thermal Infrared Radiation Parameterization for Use in General Circulation Models. Report, 85 p.

[22] Mlawer, E.J., Taubman, S.J., Brown, P.D., Iacono, M.J. and Clough, S.A. (1997) Radiative Transfer for Inhomogeneous Atmospheres: RRTM, a Validated Correlated-K Model for the Longwave. Journal of Geophysical Research, 102, 16663-16682. http://dx.doi.org/10.1029/97JD00237

[23] Mellor, G.L. and Yamada, T. (1982) Development of a Turbulence Closure Model for Geophysical Fluid Problems. Reviews of Geophysics Space Physics, 20, 851-875. http://dx.doi.org/10.1029/RG020i004p00851

[24] Janjić, Z.I. (2002) Nonsingular Implementation of the Mellor-Yamada Level 2.5 Scheme in the NCEP Meso Model. NCEP Office Note, 61 p.

[25] Smirnova, T.G., Brown, J.M., Benjamin, S.G. and Kim, D. (2000) Parameterization of Cold Season Processes in the Maps Land-Surface Scheme. Journal Geophysical Research, 105, 4077-4086. http://dx.doi.org/10.1029/1999JD901047

[26] Stockwell, W.R., Middleton, P., Chang, J.S. and Tang, X. (1990) The Second-Generation Regional Acid Deposition Model Chemical Mechanism for Regional Air Quality Modeling. Journal Geophysical Research, 95, 16343-16367. http://dx.doi.org/10.1029/JD095iD10p16343

[27] Madronich, S. (1987) Photodissociation in the Atmosphere, 1, Actinic Flux and the Effects of Ground Reflections and Clouds. Journal Geophysical Research, 92, 9740-9752. http://dx.doi.org/10.1029/JD092iD08p09740

[28] Ackermann, I.J., Hass, H., Memmesheimer, M., Ebel, A., Binkowski, F.S. and Shankar, U. (1998) Modal Aerosol Dynamics Model for Europe: Development and First Applications. Atmospheric Environment, 32, 2981-2299. http://dx.doi.org/10.1016/S1352-2310(98)00006-5

[29] Schell, B., Ackermann, I.J., Hass, H., Binkowski, F.S. and Ebel, A. (2001) Modeling the Formation of Secondary Or- 
ganic Aerosol within a Comprehensive Air Quality Model System. Journal of Geophysical Research, 106, 2827528293. http://dx.doi.org/10.1029/2001JD000384

[30] Wesely, M.L. (1989) Parameterization of Surface Resistances to Gaseous Dry Deposition in Regional-Scale Numerical Models. Atmospheric Environment, 23, 1293-1304. http://dx.doi.org/10.1016/0004-6981(89)90153-4

[31] European Commission (2010) Emission Database for Global Atmospheric Research (Edgar), Release Version 4.1. http://edgar.jrc.ec.europa.eu

[32] Tran, H.N.Q. (2012) Analysis of Model and Observation Data for the Development of a Public PM ${ }_{2.5}$ Air-Quality Advisories Tool (AQUAT). Dissertation, Department of Atmospheri Sciences, University of Alaska Fairbanks, Fairbanks, $309 \mathrm{p}$.

[33] Guenther, A. (1997) Seasonal and Spatial Variations in Natural Volatile Organic Compound Emissions. Ecological Applications, 7, 34-45. http://dx.doi.org/10.1890/1051-0761(1997)007[0034:SASVIN]2.0.CO;2

[34] Simpson, D., Guenther, A., Hewitt, C.N. and Steinbrecher, R. (1995) Biogenic Emissions in Europe 1. Estimates and Uncertainties. Journal Geophysical Research, 100, 22875-22890. http://dx.doi.org/10.1029/95JD02368

[35] Freitas, S.R., Longo, K.M., Silva Dias, M.A.F., Silva Dias, P.L., Chatfield, R., Prins, E., et al. (2005) Monitoring the Transport of Biomass Burning Emissions in South America. Environmental Fluid Mechanics, 5, 135-167. http://dx.doi.org/10.1007/s10652-005-0243-7

[36] Freitas, S.R., Longo, K.M., Chatfield, R., Latham, D., Silva Dias, M.A.F., Andreae, M.O., et al. (2007) Including the Sub-Grid Scale Plume Rise of Vegetation Fires in Low Resolution Atmospheric Transport Models. Atmospheric Chemistry and Physics, 7, 3385-3398. http://dx.doi.org/10.5194/acp-7-3385-2007

[37] Longo, K.M., Freitas, S.R., Andreae, M.O., Setzer, A., Prins, E. and Artaxo, P. (2010) The Coupled Aerosol and Tracer Transport Model to the Brazilian Developments on the Regional Atmospheric Modeling System (CATTBRAMS)—Part 2: Model Sensitivity to the Biomass Burning Inventories. Atmospheric Chemistry and Physics, 10, 5785-5795. http://dx.doi.org/10.5194/acp-10-5785-2010

[38] Sestini, M., Reimer, E., Valeriano, D., et al. (2003) Mapa De Cobertura Da Terra Da Amazônia Legal Para Usa Em Modelos Meteorológicos. Anais XI Simpósio Brasileiro de Sensoriamento Remoto, 2901-2906.

[39] Olson, J., Watts, S. and Allison, L.J. (2000) Major World Ecosystem Complexes Ranked by Carbon in Live Vegetation: A Database (Revised November 2000). Carbon Dioxide Information Analysis Center, Oak Ridge National Laboratory, Oak Ridge.

[40] Andreae, M.O. and Merlet, P. (2001) Emission of Trace Gases and Aerosols from Biomass Burning. Global Biogeochemical Cycles, 15, 955-966. http://dx.doi.org/10.1029/2000GB001382

[41] Ward, D.E., Susott, R.A., Kaufman, J.B., Babbitt, R.E., Cummings, D.L., Dias, B., et al. (2002) Smoke and Fire Characteristics for Cerrado and Deforestation Burns in Brazil: Base-B Experiment. Journal of Geophysical Research, 97, 14601-14619. http://dx.doi.org/10.1029/92JD01218

[42] Freitas, S.R., Longo, K.M. and Andreae, M.O. (2006) Impact of Including the Plume Rise of Vegetation Fires in Numerical Simulations of Associated Atmospheric Pollutants. Geophysical Research Letters, 33, Article ID: L17808. http://dx.doi.org/10.1029/2006GL026608

[43] Department of Commerce (2000) NCEP FNL Operational Model Global Tropospheric Analyses, Continuing from July 1999. Research Data Archive at the National Center for Atmospheric Research, Computational and Information Systems Laboratory. http://rda.ucar.edu/datasets/ds083.2

[44] Mölders, N., Gende, S. and Pirhalla, M.A. (2013) Assessment of Cruise-Ship Activity Influences on Emissions, Air Quality, and Visibility in Glacier Bay National Park. Atmospheric Pollution Research, 4, 435-445. http://dx.doi.org/10.5094/apr.2013.050

[45] Leelasakultum, K., Mölders, N., Tran, H.N.Q. and Grell, G.A. (2012) Potential Impacts of the Introduction of Low Sulfur Fuel on $\mathrm{PM}_{2.5}$-Concentrations at Breathing Level in a Subarctic City. Advances in Meteorology, 2012, Article ID: 427078. http://dx.doi.org/10.1155/2012/427078

[46] Sassen, K. (1991) The Polarization Lidar Technique for Cloud Research: A Review and Current Assessment. Bulletin of the American Meteorological Society, 72, 1848-1866. http://dx.doi.org/10.1175/1520-0477(1991)072<1848:TPLTFC >2.0.CO;2

[47] Sassen, K. (2005) Dusty Ice Clouds over Alaska. Nature, 434, 7032, 456-456. http://dx.doi.org/10.1038/434456a

[48] Sassen, K. (2008) Boreal Tree Pollen Sensed by Polarization Lidar: Depolarizing Biogenic Chaff. Geophysical Research Letters, 35, Article ID: L18810. http://dx.doi.org/10.1029/2008gl035085

[49] Martins, J.V., Hobbs, P.V., Weiss, R.E. and Artaxo, P. (1998) Sphericity and Morphology of Smoke Particles from Biomass Burning in Brazil. Journal of Geophysical Research, 103, 32051-32057. http://dx.doi.org/10.1029/98JD01153

[50] Murayama, T., Müller, D., Wada, K., Shimizu, A., Sekiguchi, M. and Tsukamoto, T. (2004) Characterization of Asian 
Dust and Siberian Smoke with Multi-Wavelength Raman Lidar over Tokyo, Japan in Spring 2003. Geophysical Research Letters, 31, Article ID: L23103.

[51] Sassen, K. (2008) Identifying Atmospheric Aerosols with Polarization Lidar. In: Kim, Y.J. and Platt, U., Eds., Advanced Environmental Modeling, Springer Science + Business Media Inc., New York, 136-142. http://dx.doi.org/10.1007/978-1-4020-6364-0 10

[52] Lee, C.H., Kim, J.H., Park, C.B., et al. (2004) Continuous Measurements of Smoke of Russian Forest Fire by 532/1064 $\mathrm{nm}$ Mie Scattering Lidar at Suwon, Korea. Proceedings of the 22nd International Laser Radar Conference, Matera, 12-16 July 2004, 535-538.

[53] Vautard, R.M.M., Solazzo, E., Gilliam, R.C., Matthias, V., Bianconi, R.C.C., Ferreira, J., Geyer, B., Hansen, A.B., Jericevic, A., Prank, M., et al. (2012) Evaluation of the Meteorological Forcing Used for the Air Quality Model Evaluation International Initiative (AQMEII) Air Quality Simulations. Atmospheric Environment, 53, 15-37. http://dx.doi.org/10.1016/j.atmosenv.2011.10.065

[54] Menut, L., Tripathi, O.P., Colette, A., Vautard, R., Flaounas, E. and Bessagnet, B. (2013) Evaluation of Regional Climate Simulations for Air Quality Modelling Purposes. Climate Dynamics, 40, 2515-2533. http://dx.doi.org/10.1007/s00382-012-1345-9

[55] PaiMazumder, D., Henderson, D. and Mölders, N. (2012) Evaluation of WRF-Forecasts over Siberia: Air Mass Formation, Clouds and Precipitation. The Open Atmospheric Science Journal, 6, 93-110. http://dx.doi.org/10.2174/1874282301206010093

[56] Madden, J.M. (2014) Using WRF/Chem, In-Situ Observations, and CALIPSO Data to Simulate Smoke Plume Signatures on High-Latitude Pixels. Master's Thesis, Department of Atmospheric Sciences, University of Alaska Fairbanks, Fairbanks, 106 p.

[57] Mölders, N. (2008) Suitability of the Weather Research and Forecasting (WRF) Model to Predict the June 2005 Fire Weather for Interior Alaska. Weather and Forecasting, 23, 953-973. http://dx.doi.org/10.1175/2008WAF2007062.1

[58] Hines, K.M., Bromwich, D.H., Bai, L.-S., Barlage, M. and Slater, A.G. (2011) Development and Testing of Polar WRF. Part III: Arctic Land. Journal of Climate, 24, 26-48. http://dx.doi.org/10.1175/2010JCLI3460.1

[59] Hines, K.M. and Bromwich, D.H. (2008) Development and Testing of Polar Weather Research and Forecasting (WRF) Model. Part I: Greenland Ice Sheet Meteorology. Monthly Weather Review, 136, 1971-1989. http://dx.doi.org/10.1175/2007MWR2112.1

[60] Steeneveld, G.J., Ronda, R.J. and Holtslag, A.A.M. (2015) The Challenge of Forecasting the Onset and Development of Radiation Fog Using Mesoscale Atmospheric Models. Boundary-Layer Meteorology, 154, 265-289. http://dx.doi.org/10.1007/s10546-014-9973-8

[61] Pirhalla, M.A., Gende, S. and Mölders, N. (2014) Fate of Particulate Matter from Cruise-Ship Emissions in Glacier Bay during the 2008 Tourist Season. Journal of Environmental Protection, 4, 1235-1254. http://dx.doi.org/10.4236/jep.2014.512118

[62] Mölders, N. and Kramm, G. (2007) Influence of Wildfire Induced Land-Cover Changes on Clouds and Precipitation in Interior Alaska-A Case Study. Atmospheric Research, 84, 142-168. http://dx.doi.org/10.1016/j.atmosres.2006.06.004

[63] Hinzman, L.D., Fukuda, M., Sandberg, D.V., Chapin III, F.S. and Dash, D. (2003) FROSTFIRE: An Experimental Approach to Predicting the Climate Feedbacks from Changing Boreal Fire Regime. Journal of Geophysical Research, 108, 8153. http://dx.doi.org/10.1029/2001jd000415

[64] Mölders, N. (2011) Land-Use and Land-Cover Changes-Impact on Climate and Air Quality. Springer, Heidelberg, $193 \mathrm{p}$.

[65] Seinfeld, J.H. and Pandis, S.N. (1997) Atmospheric Chemistry and Physics, from Air Pollution to Climate Change. John Wiley \& Sons, New York, 1326 p.

[66] Yarker, M.B., PaiMazumder, D., Cahill, C.F., Dehn, J., Prakash, A. and Mölders, N. (2010) Theoretical Investigations on Potential Impacts of High-Latitude Volcanic Emissions of Heat, Aerosols and Water Vapor and Their Interactions on Clouds and Precipitation. The Open Atmospheric Science Journal, 4, 24-44. http://dx.doi.org/10.2174/1874282301004010024

[67] Ruiz, J.J., Saulo, C. and Nogués-Paegle, J. (2010) WRF Model Sensitivity to Choice of Parameterization over South America: Validation against Surface Variables. Monthly Weather Review, 138, 3342-3355. http://dx.doi.org/10.1175/2010MWR3358.1

[68] Zhang, J.L., Campbell, J.R., Reid, J.S., Westphal, D.L., Baker, N.L., Campbell, W.F. and Hyer, E.J. (2011) Evaluating the Impact of Assimilating CALIOP-Derived Aerosol Extinction Profiles on a Global Mass Transport Model. Geophysical Research Letters, 38, Article ID: L14801. http://dx.doi.org/10.1029/2011gl047737 